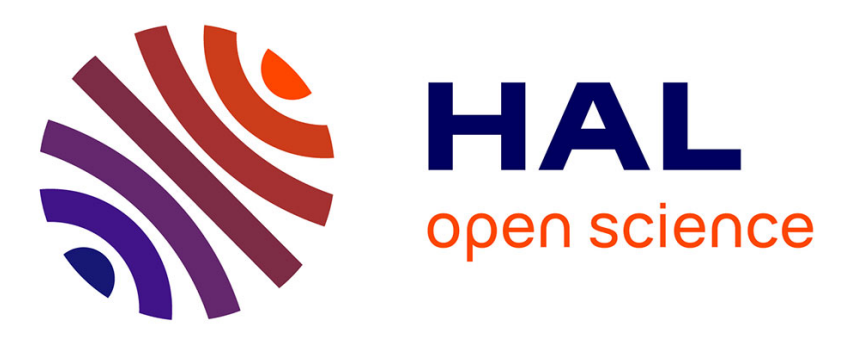

\title{
Deleuze, Cinema and Acousmatic Music (or What If Music Weren't an Art of Time?)
}

\author{
Nicolas Marty
}

\section{To cite this version:}

Nicolas Marty. Deleuze, Cinema and Acousmatic Music (or What If Music Weren't an Art of Time?). Organised Sound, 2016, Situating the Avant-Garde: Conformity and oppositional culture, 21 (2), pp.166-175. 10.1017/S1355771816000091 . halshs-01340691

\section{HAL Id: halshs-01340691 https://shs.hal.science/halshs-01340691}

Submitted on 1 Jul 2016

HAL is a multi-disciplinary open access archive for the deposit and dissemination of scientific research documents, whether they are published or not. The documents may come from teaching and research institutions in France or abroad, or from public or private research centers.
L'archive ouverte pluridisciplinaire HAL, est destinée au dépôt et à la diffusion de documents scientifiques de niveau recherche, publiés ou non, émanant des établissements d'enseignement et de recherche français ou étrangers, des laboratoires publics ou privés. 


\title{
Deleuze, cinema and acousmatic music. (or What if music weren't an art of time?)
}

\begin{abstract}
Drawing on Deleuze's work about cinema (the 'movement-image' and the 'timeimage'), this paper explores formal and aesthetic resonances with sound-based music, distinguishing between aesthetics of energy, articulation and montage, and aesthetics of contemplation, space and virtual relations. A second perspective is given, focusing on how listening behaviors may impose a 'movement-image' or a 'time-image' lens through which we could experience and remember a work's form. This is exemplified with a short analysis of the first section of Chat Noir (1998-2000) by Elizabeth Anderson.
\end{abstract}

Gilles Deleuze has been one of the most prominent philosophers of the $20^{\text {th }}$ century. In Milles plateaux (1980), he introduced with Félix Guattari the notion of 'rhizome' to designate that multifaceted, complex and nonhierarchical system of relations, constituting a wider perspective than that of the genealogical, binary, causal and hierarchical tree, which constitutes a state of being rather than becoming. Whereas psychoanalysis explains the human mind by reference to the patient's past traumas, the notion of rhizome tends to emphasize the systemic nature of the mind, its plural relations to past, present and future. In another domain, the rhizome is apt in describing pack animals' movements and other group behaviors (Sutton \& Martin-Jones 2008: 3-6).

What one should understand is that tree and rhizome do not form a binary category, but rather different perspectives on the same phenomena: when looking at the tree, one could forget its roots and consider it to be going upwards only; when considering the rhizome, one takes into account the tree's roots and their relations with other roots which may emerge as other trees or other forms of life. Instead of analyzing, for instance, how the form and deviation of the tree's trunk led to its being somehow crooked, we may look at how each branch's movement relates to other branches' movements, more or less independently of the trunk; we may be interested in how this tree's roots are actually longer than its emerging part, and how they are intertwined with what surrounds them, etc. With this in mind, we may ponder about how the way we look at things actually determines a lot more than we would like to admit.

The main question leading this paper will be: what if music weren't an art of time? Gisèle Brelet asserted that music was the art of time par excellence, consisting essentially in 'the discovery of the temporal structures of consciousness and their translation in the only sense that could translate them: sound' (1949: 632). I have often heard this point of view, as a student in music and musicology, modulated according to context, but it all boils down to the following: unlike sculpture or architecture, music isn't constituted of physical objects, so it could not be an art of space; furthermore, we do not have any control over its temporal unfolding (we cannot go back in time), and therefore, music must be an art of time. This is an ontological perspective on music and the arts in general. What I would like to propose here is not meant to replace this perspective, but to complement it with another possibility focusing on human processes rather than ontology. 
My approach will be an intermedial one, using Deleuze's concepts about cinema to shed some light on how we could apprehend sound-based music (or rather musical form) in several contrasting ways. The aim is not to study how cinema techniques were recuperated by electroacoustic music (for a discussion of this, see Langlois 2012 and Brunson forthcoming), nor is it to explore the sociopolitical issues related to the use of certain kinds of images (for a discussion about this, see Sutton \& Martin-Jones 2008). Rather, after having presented the 'movement-image' and the 'time-image', their formal and aesthetic correspondences with music will be explored, in order to pave the way for a discussion about how the 'time-image' might be discovered, poietically and esthesically, in acousmatic music.

\section{Deleuze and cinema}

Whereas he didn't write extensive work about music, Deleuze dedicated two books to the study of cinema, distinguishing between cinema before and after World War 2 (L'image-mouvement, 1983; L'image-temps, 1985). This does not mean that any and all movies from 1945 onwards respond to the characteristics of the 'time-image', but that a new kind of relation to time and space in movies appeared at that time, after a period of transition.

\subsection{The movement-image}

Before World War 2, cinema relied nearly exclusively on 'movement-images'. Deleuze (1983) defines the movement-image as being focused on characters and their reaction to the situations they're exposed to - this is what he calls the 'sensorimotor link'. This means that the camera followed characters wherever they went, and that every sequence served the narrative thread. This also means that time was represented linearly, and that ellipses served the sole purpose of allowing the representation of durations greater than the duration of the movie itself (see also Sutton \& Martin-Jones 2008: 92-93). This was the case with most western movies, among other genres.

Deleuze distinguished three main kinds of movement-images, related to perception, affection and action. The 'perception-image' represents the perception of the situation by the character - not perception for its own sake, but perception of a situation that will affect the character - this will be represented in the 'affection-image'. In turn, the character will react upon the situation in order to modify it - which will imply the 'action-image'. A hypothetical example may help clarify this: watching a western movie, we may see a wide shot of a ghost town, centered on a character looking around in the street (perception-image). As a door creaks on the right, the character turns her head towards it, and we see a close shot of her eyes fixed on the source of the noise (affection-image). The camera goes to a medium shot, allowing us to see both the character and the house in front of her. She points her gun at the wall next to the door and shoots to kill (action-image). Now it really is a ghost town, and the camera may go back to a wide shot, or pursue with the character searching for the body of the person she just killed (new perception-image) to confirm their death and eventually show contentment (new affection-image) and leave town (new action-image). The whole situation is depicted linearly, the camera follows the character in the house, and the whole point of the sequence is to depict what has been described here, then follow up with the narrative.

\subsection{The time-image}

The years surrounding World War 2 saw the advent of a new kind of temporality in cinema, which Deleuze called the 'time-image' (1985 - see also Sutton \& Martin-Jones 2008: 93-96). Deleuze credits Hitchcock with the overthrowing of the movement-image and the use of 'mental images', implying new relations of the camera to the spaces, characters and images of the movie. This is the time that filmmakers began using flashbacks in their movies, not only to explain the action taking place in the present, but also to put forward the fundamental relativity of memory (as is the case in Citizen Kane in 1941). This is also the time that trivial scenes, that would have been cut out from 'action' movies, began to be integrated (in 1952, in Umberto D, de Sica films the maid doing her housework, which brings no new information regarding the narrative but anchors it in everyday reality). In such contexts, wide shots of landscape and close shots of faces do not imply an incoming action. Rather, they are there to be read, to be compared, to be understood, to reveal time in itself: this face for five seconds, this landscape for twelve and a half seconds, this long take of people picking apples far away for some 
time, etc. Deleuze distinguished between two main kinds of time-images, according to whether the relations to be read are actual or virtual.

'Optical-images' imply actual optic relationships. The viewer is given some time to read these relationships. Perception is replaced by existence, as in the beginning of 2001: A Space Odyssey (1968), with its static shots of landscapes, or in the unfolding of Ozu's Tokyo Story (1953) in which the camera often stays put for some time while characters move around, enter and leave the room. Affection may be replaced by close shot portraits, as in Robbe-Grillet's L'homme qui ment (1968) in which portraits are inserted at several points without any narrative reason for it, or Ozu's Tokyo Story again, in which the characters who are talking are often filmed looking straight into the camera, mostly without any context. Action is replaced by the moving around of figures in space, those figures being related to each other by measures of distance or closeness, between them and to the camera, as we often see in the unfolding of 2001: A Space Odyssey, for instance when the character goes out in space to repair the ship.

'Crystal-images', instead of readable optical relations, imply virtual relations. These can be related to memory (like in the uncertain, multifold past of Citizen Kane), lying (in L'homme qui ment, at the beginning, the narrator says the bar was empty while the image is showing him entering a bar full of people), mise en abyme (in 2001: A Space Odyssey, the camera actually appears on screen in the last section, filming the protagonist), etc. All of these relations imply reflection on the part of the viewer, in one way or another. The crystal shows several coexisting realities (present or past); time is given in itself and turned on itself; the viewer is left to link everything together and draw conclusions.

\subsection{Deleuze interpreted by Bonnet}

Recently, Antoine Bonnet, a French composer, wrote that Deleuze's thought about the arts is not supposed to shed light on the one art it actually talks about, but to inform readers on much more general 'modes of thought' that could be exploited for a number of situations and objects (2015: 82). Borrowing Deleuze's concepts about cinema, Bonnet describes the evolution of music at the turn of the $20^{\text {th }}$ century. Interestingly enough, 'atonality' is not the topic of his talk, thematicism is.

The parallel between a musical theme in classical-tonal music and what Deleuze describes as a character reacting to a situation in a movement-image is quite clear: at the heart of the sensorymotor scheme, the theme both implies and reveals a given situation ("perception-sound"), forms its expression in the foreground ("affection-sound"), modifies and measures its formal evolution ("action-sound"). Conversely, in modern-atonal music, the theme, precisely because it isn't a theme per se anymore, becomes incapable of reflection, expression or inflexion on any situation, because it appears in any situation as a constitutive element amongst other elements, or even as a simple marking. (ibid.: 83)

The theme and its development are not the topic of music anymore. 'Themes' appear and disappear without getting more important or more salient than other constitutive materials. Bonnet asserts that Wagner, with his leitmotifs, initiated the 'crisis' by proposing themes whose development doesn't concern themselves, but their context, their relations with what surrounds them (ibid.: 84). Then Debussy, under the influence of Wagner, ruptured the sensorimotor link of music, preferring colors and floating time over melodic articulation. Composers in the $20^{\text {th }}$ century then developed music's 'depth of field', using superimposition, juxtaposition, hierarchies and distributions of planes: 'on the scale of the century's modernity, this resulted in the generalization of complementary and superimposed strata in composition, at the expense of causal and linear successions' (ibid.: 85).

\subsection{Preliminary discussion}

Although this perspective is interesting, its limits should not be overlooked. The main bias to be found here is the fundamental arbitrariness of the correspondences, which appears in the one-to-one relationship established between the three movement-images and the roles of themes in thematic music. Perception-images, affection- 
images and action-images seem extremely specific to cinema and cinematic narrative. Whereas Bonnet's perspective is that of an artist, a composer (studying how one could conceive one's work, one's materials), forcing such a correspondence might not be the ideal way to explore Deleuze's notions musicologically.

At a higher level of abstraction, the sensorimotor link of the movement-image finds its correspondence in music with theme development and energetic articulation: wherever the main material goes, the 'camera' follows; an energetic climax in a sound is an opportunity for an energetic climax in the whole piece; the whole form is to be regarded as directional, teleological, linear; 'musical time' emerges from the articulation and development of materials in time and establishes a direction, a speed, a nature of time passing different from that of our everyday experience. The time-image finds its correspondence in music with fragmented forms and extended static situations left to be read - this will be explored further.

Besides the movement-image and the time-image, Sutton and Martin-Jones define another kind of image in more recent cinema, which they call the 'hybrid-image' (2008: 99 sq.). This name points out the coexistence of both movement-images and time-images in many movies and music videos nowadays. They show how Singh's The Cell (2000) can be described as a movement-image overall, since there is a clearly delineated plot and clear-cut characters with a linear development (a killer in a coma, his last victim about to die somewhere, the FBI and a psychologist working together to find the victim and save her), as well as scenes of another nature, where camera cuts seem irrational and arbitrary, where images are of a more symbolic nature, where chronology and the sensorimotor link seem abolished altogether - this second kind of scenes taking place in the killer's psychotic mind. Although Sutton and Martin-Jones refer to The Cell as a hybrid-image, they concede that this movie, just like many other movies made nowadays - the Wachowskis' The Matrix (1999), Jonze's Being John Malkovitch (1999), Nolan's Memento (2000), etc. - is mostly a movement-image with a clear narrative thread, where the time-image serves the purpose of representing sick minds, dreams, drug-induced states, or other 'abnormal' characters, situations or phenomena.

Instead of using the time-image for its own sake, with its own dialectics and its own potential developments, moviemakers nowadays seem to be motivated by the contrast it offers with the normal, with the movementimage. Instead of offering people necessary reflexivity in movies, we give them an all-made explanation: this weird thing happening does not need to be understood for itself, to be reflected upon, it is simply the manifestation of an abnormal state that may help explain the story.

We may find this same relation in music, in the articulation of tension and release, dynamic and static sections, etc. The following section will underline different natures of space and time in music, as well as the musical entities that may emerge from these natures. This will allow us to see how the time-image, rather than the movement-image or the hegemonic hybrid-image, may be used as an aesthetic descriptor, an analytical model and a listening behavior to shed some new light on acousmatic music.

2. Space, time and entities in music

Among musicological works, we may find some aesthetic distinctions which may immediately find some resonance with movement-images and time-images.

\subsection{Energies and entities in music}

Bériachvili defines, among other musical spaces, form-space as an imaginary vision of quasi-geometrical relations between sound elements' in spatialized time, and matter-space as 'sound matter (...) putting forward associations with colors, lighting effects, haptic feelings, physical materiality, etc.' (2010:12). He distinguishes between two kinds of articulation of these two spaces, delineating two aesthetic stances. In expressionist space (espace expressif), form-space is foremost, matter being only a more or less auxiliary attribute (typical examples include expressionist atonal music, Stockhausen's serialism, a large part of Boulez's serialism, etc.): this is the expressive mode, 'action time' (ibid.: 107). On the other hand, in impressionist space (espace impressif), 'any movement (...) is perceived as an attribute of sound-matter (best examples may be Xenakis and a lot of Varèse and Debussy)' (ibid.: 54). Here, 'perception equals contemplation of musical space, while the time of music unfolds “objectively” without merging with our interiority’ (ibid.: 107). 
This distinction is also found in the opposition of musique concrete and musique acousmatique as seen by Schaeffer. Battier reports that to Schaeffer, the montage of sound-objects gives rise to time in musique concrete, while in musique acousmatique, time gives life to sound-objects, allows them to develop (2013: 708). With the former, objects are articulated expressively in time, bending time to their inner development; with the latter, objects are born, live on for some time, revealing progressively their multifaceted nature while keeping a sense of identity.

Khosravi (2012) talks of 'autonomous spectromorphological entities' to designate those sounds, living through time in an acousmatic environment and which may acquire a form of autonomy, of life-like, zoomorphic existence. At that point, musical entities are spatial rather than temporal, and another kind of relation to music may be instated: the 'space-form'.

\subsection{Space-form and momentform}

Denis Smalley (2007) defined the 'space-form' as this musical form where time serves space rather than being articulated by it - the notion of coexistence thus being more relevant than that of succession. Describing his listening experience of a soundscape, he writes that

Possibly the most important strategy in arriving at an holistic view of the space-form of this experience is that I disregard temporal evolution: I can collapse the whole experience into a present moment, and that is largely how it rests in my memory. The temporal disposition of, and relations among, sounds serve to articulate and shape spectral and perspectival space, but even though my perception of sound is the product of time, I ultimately sideline time's formative role. (2007: 38)

Time does not disappear, however: the unfolding of the space-form implies expectancies about continuity, change, ruptures, etc. (ibid.: 54). One piece of music could be a single space, or it could be developed as a succession of spaces, establishing virtual relations between spatial forms, movements, actual relations, potential relations and the interweaving of time and space. We may find this again in the concept of momentform, introduced by Stockhausen to designate those contemporary musical forms in which the whole is contained in each of its parts - implying the absence of any ontological beginning and end of the work, by contrast with 'dramatic forms' with their 'necessary' successive episodes, their 'conclusive force', the 'emotion' induced by tension, etc. (1988: 102). Such works, in fact, 'have always already begun and can go on without limit' (ibid.: 110).

Kramer, in his book about the time of music, interpreted this notion of moment as delineating a 'moment time', where moments happen one after the other without their order necessarily being relevant, although they are organized in such a way that they form an entire piece (1988: 50). In this perspective, each moment is a spaceform, and the grouping of all those moments reveals a momentform. In its relation to time, momentform is thus quite close to the crystal-image's interest towards fragmentation: time is given directly without any notion of progression, causality or directionality, as a segmented space-form. Time is not the medium of discourse anymore, it is either its topic or its container.

\subsection{Relevant features in acousmatic music scores}

To illustrate the inclusion of temporal parameters in a space-form, we may consider a crossroads in a city, such as the one used by Leigh Landy to exemplify the cyclic nature and divisibility of soundscapes: theoretically, we should never hear pedestrians' footsteps at the same time as the sound of cars moving. This soundscape is regulated by the cycle of traffic lights (2012: 44-45). We may go even further, studying Landy's transcriptions of yet another soundscape: his sequential score (Figure 1, on the right) reveals the systematic simultaneity of children playing and the sounds of the factory, as well as the regularity of church bells and trains, while cars and birdsongs seem to be linked somehow. But are those elements really of interest to us? Wouldn't we rather know, when listening to a soundscape, where each sound event, each sound entity is situated in the spatial setting? This is what is indicated in the spatial score (Figure 1, on the left): the church and factory are quite far away, cars are 
close to the factory, the train goes left to right and closer to the front, the school is rather distant on the right, overflown by birds, and there seems to be another element, a pond with a swan in it.
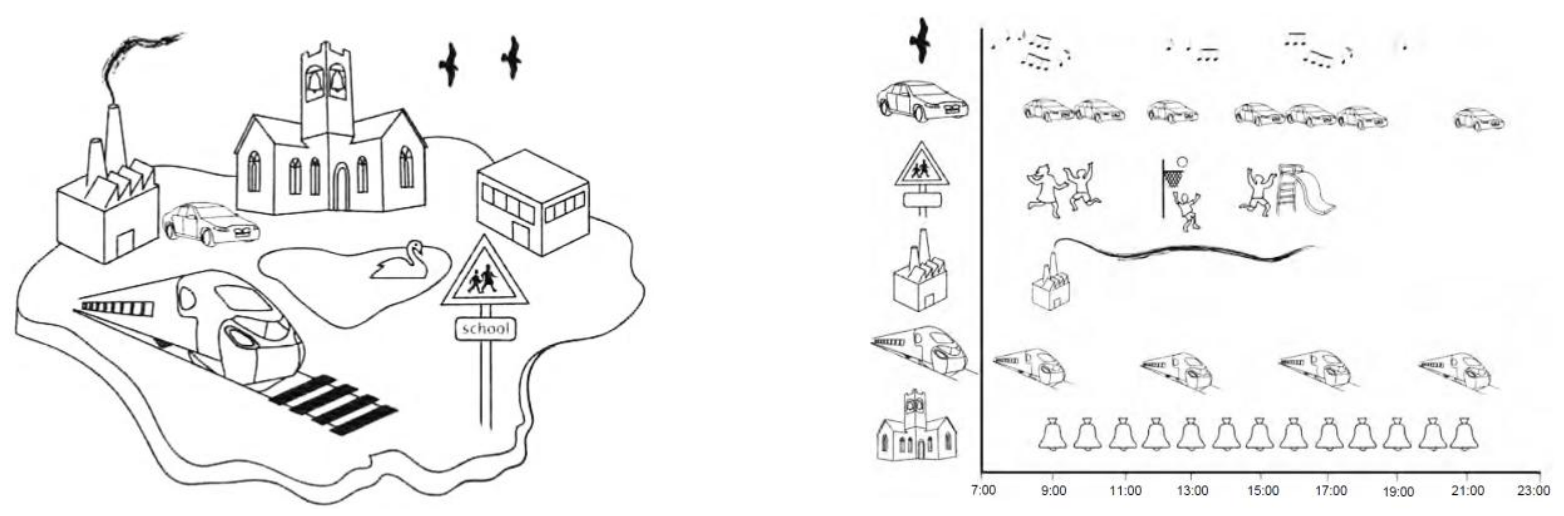

Figure 1. Two proposals for the transcription of a soundscape (Landy 2012: 36-37).

On the right, we have no indication about space. On the left, we have no indication about chronology. In this depicted space-form, relationships between musical entities are systemic, hierarchical and spatial rather than energetic, chronological and causal.

3. The time-image in acousmatic music

The distinction between movement-image and time-image, established by Deleuze about cinema, thus seems to find its parallel in music. Bériachvili distinguished between espaces expressifs and espaces impressifs. The first of these concerns movements (space), following one another ruled by sensorimotor causality; they happen through time and allow time's structuration. We could think of expressive, articulated montage in musique concrète, where the sensorimotor link still rules. On the other hand, espaces impressifs concern time and duration; sequences follow one another in a rather arbitrary manner, each representing a sustainable, lasting space. Time unfolds in space and allows its structuring - movements, coexistences, alternations, all become proprieties of space; causality and succession lose their relevance. We could talk about acousmatic 'montrage', which is to say that we are 'shown' a space, an 'image-de-son', to be observed and read rather than to be experienced empathically. Figure 2 illustrates this duality, where movement may be articulated through or contained in time.
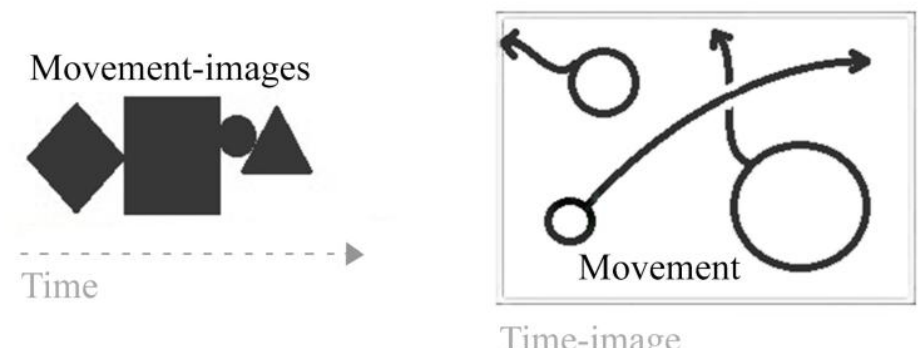

Figure 2. Movement-images over time and a time-image containing movement.

\subsection{The time-image as a form or an aesthetic stance}

It is quite clear already that some musical works, due to their structures and languages, may fall in the expressionist category - keeping the dialectics between high-energy and low-energy sections, tension and release and a somewhat narrative thread (this is what appears in many acousmatic works nowadays) - while other works 
may fall in the impressionist category (putting aside the energetic dialectics to focus on something else) and be considered 'time-images'.

The 'time-image', in this sense, can be related to two musical forms: it is a momentform, whose beginning and end are arbitrary and whose plans are individual and articulated in a somewhat arbitrary manner; it is also a space-form, in which time serves the unfolding of space, whose main point is to establish spatial relations between entities rather than causalities and successions, and which should be, in that regard, listened to as we would a soundscape.

Porträten (2014) and Porträten Tvō (2015) by Cara Arndt ${ }^{1}$ are exemplary from this point of view, each offering six portraits of a specified arbitrary duration (as well as a 'clotted blood insert'), the topic of the work being the identity of each portrait and the putting together of contrasting portraits, none of which have any teleological development. We could call each portrait an 'optic-image', while the whole form would be a 'crystal-image'.

The crystal-image may be explored further, in its relation to reality, memory and time. How could time be folded on itself in electroacoustic music? Trevor Wishart's Journey into Space (1972) is founded on the ambiguity between reality and daydream, between trivial reality and the everyday routine of the average worker. This is manifest, in the work, in the transition between apparently straight recording of everyday scenes and more abstract material; this appears again at one of the climaxes of the work, when the 'waking up' sequence is played and repeated several times to figure routine. ${ }^{2}$

Furthering our exploration of the crystal-image, Luc Ferrari’s Presque rien $n^{\circ} 2$, ainsi continue la nuit dans ma tête multiple (1977), besides its anecdotal nature (which makes it eligible to be described as a time-image already), includes lies from Ferrari about his whereabouts and about the reality his voice is describing in the piece. In fact, the voice has been added afterwards to make it sound like Ferrari is exploring the soundscape, microphone in hand, and discovering it at the same time as we do, whereas in fact everything was constructed in a studio. The piece also features ambiguities about reality, as the anecdotal soundscape is progressively invaded by more electronic sounds, allegedly coming from within Ferrari's 'multiple head', a process used in three out of the four acousmatic Presque Rien. ${ }^{3}$

These three examples show how we could analyze specific pieces or groups of pieces in order to assess whether they present characteristics of the time-image in their conception, their construction, their sound content, etc. This forms the poietics of analysis. Let us now turn towards the aesthesics of the time-image.

\subsection{The time-image as a reception behavior}

Smalley was abundantly clear on the fact that the listener may disregard temporal evolution and not retain it as a relevant feature for the formal imprint of the piece. This means that listeners may actually decide to listen to a piece of music as if it were a time-image, even if the piece does not present clear poietic or structural characteristics of a time-image.

The beginning of 2001: A Space Odyssey is a group of static wide shots, following one another, with certain durations and certain readable optic relations. Nothing in the movie indicates whether those shots are supposed to represent different moments presented chronologically, as well as different places, or if they are supposed to be the same moment in those different places. This ambiguity allows us to watch this prelude with no notion of a chronology of events, although it wasn't necessarily conceived that way. We may in the same way listen to some (or maybe to most) sound-based works without the need for successive sections to be formally understood as a linear succession. In that regard, even a work that was composed and conceived chronologically might sometimes be listened to in such a way that it becomes a time-image.

1 Both works may be found at https://soundcloud.com/caraarndt [05/07/2015].

$2 \quad$ For a deeper analysis of this piece, see Marty (2014).

3 For a deeper analysis of the series of Ferrari's Presque Rien, see Marty (2012). 
This is linked with the notion of 'reception behavior' as 'this act, where objective, strategy, perceptual construction, symbolisations, and emotions are mutually dependent and progressively adapt to the object' (Delalande 1998: 23) ${ }^{4}$. A listening behavior imposes a framework for the reception of a piece of music or sound art by selecting pertinences, without predefining any content for this piece. The point, here, is to say that one work could be listened to, apprehended and remembered in very different ways according to whether listeners considered chronology as being relevant or not to the form of the work.

\subsubsection{Chat Noir}

As an example, we may take Chat Noir, by Elizabeth Anderson. Chat Noir, composed between 1998 and 2000 , belongs to the 'Janus trilogy' (named that way in the recent online edition by empreintes DIGITALes) inspired by Robert Johnson's Owning Your Own Shadow (1991), a psychoanalytical account of the repression of our inner child because of society's norms, and the possibility to accept paradoxes in order to reconcile apparently opposite elements without them losing their force. In Anderson's work, opposites are found in the use of different timescales, as well as in the coexistence of very diffuse wefts and very clear, crispy sounds. Here, I will focus on the first two minutes of the work, which form, in my experience, a clearly delimited section divided in two subsections.

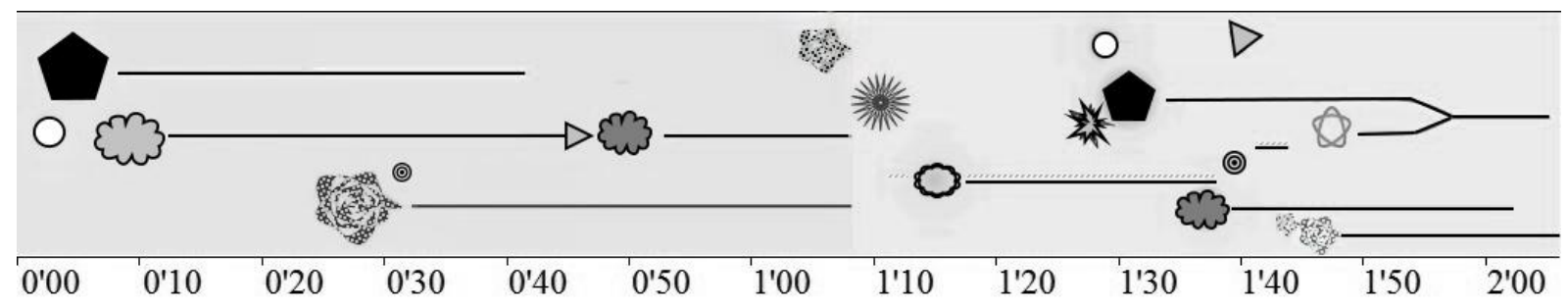

Figure 3. Chat Noir - listening score for the first two minutes of the piece ${ }^{6}$.

As illustrated in Figure 3, the section begins with an articulation $\bigcirc$ leading to a sustained modulated high B $(1000 \mathrm{~Hz})$. A whole-tone harmonic field appears in the background as a weft $\mathrm{m}_{3}$, followed by a low, noisy, granular sound internally articulated by dystonic dry percussions ${ }^{7} \odot$. While the high B disappears, the harmonic field becomes inharmonic $\mathrm{m}^{\mathrm{s}}$ and widens toward low frequencies. The whole spectra densifies and widens in space until its culminating point around 1'00, with the emergence of a new noisy sound 5 in the foreground. Energy is directed towards a rupture point at 1'07, with three punctuations opening up the second subsection. Everything is muted while a modulated C\# axis $O$ appears far away. Around 1'25, a new articulation $\mathrm{O}$ brings back the high B, the inharmonic weft, the dystonic dry percussions and the noisy sounds in the background. A thin shrill granulation $D$ appears briefly around 1'37, while a high vortex emerges around 1'45, closing up the section with a morendo between 1'55 and 2'05 on the high B from the beginning.

It is quite clear how this section, taken sequentially, reveals two goal-oriented processes: in the first minute, the spectrum widens towards low frequencies until rupture; in the second minute, the spectrum

$4 \quad$ For studies about listening behaviours in this framework (with the distinction between empathic, figurative and taxonomic behaviours), see Alcazar (2015), Anderson (2011), Delalande (1989, 2010, 2013), Marty (2015a), Marty \& Terrien (2015).

$5 \quad$ For a larger account about Elizabeth Anderson and the poietics of Chat Noir, see Marty (2015b). Elizabeth Anderson's works may be consulted and bought from empreintes DIGITALes [http://www.electrocd.com/bio/anderson_el/discog/].

6 In this greyscale version of the score, as colors have been removed, some symbols have been changed to most aptly render the distinction between sounds. For a colored version of the score, see Marty \& Terrien (2015). To listen to this extract, refer to www.musimediane.com/delatour_marty, on the page of the chapter from Marty \& Terrien (or contact the author).

\footnotetext{
$7 \quad$ "Dystonic" refers to a sound whose spectral content presents both nodes (noise bands) and inharmonic content.
} This is the translation coined by Lasse Thoresen for Schaeffer's "son cannele". 
widens both way and closes up again. Some local internal energy appears in the modulated sounds and in the unfolding of wefts and granulations, participating in the general forward-oriented motion.

\subsubsection{The time-image as model for listener-oriented analysis}

How could we analyze Chat Noir (or other acousmatic works) as a time-image, as a space-form? We would have several optic-images, separated by montage between sections (notably, strong surface contrasts that could not be missed) or 'travelling' of the acousmatic camera. All of these optic-images could be collated together to make up a single space, a single world, of which we could explore mentally time and spaces, as well as potential relations, even though they might not have been presented in the piece.

It was noted by Cipollone (2013) that the systematic two-dimensionality of musical scores influences how we listen to music (and how we conceive of music - in my experience, it is often hard for students to understand how they could realize a static score that does not include time indications). Landy's proposals (see above) are a good remedy to this situation, as are new transcription tools like Couprie's EAnalysis (see Couprie 2015), allowing free choice over dimensional mapping of acoustic and musical characteristics. Here, I will propose a 'spatial' score, by which I mean that the space of the score will try to be analogous, up to a certain point, to the sonorous space that might be perceived, while time will be integrated in the score as little as possible, only to indicate montage points and transitions, while sections will be transcribed spatially.

It is necessary to define how components are to be analyzed, their characteristics and their functions. Since we're not interested in chronology and causality, we'll be most concerned with the spatial and systemic relations between entities (by contrast with the chronological outline or the unfolding of articulation, energy and causality). A classification of entities' functions is necessary in order to have a solid ground for analysis. With this aim in mind, it seems relevant to borrow Schafer's terminology about the study of soundscapes (1977), where chronology has very little importance compared with the actual roles of sound events and their systemic organization.

1. Background wefts are those sounds that are less salient, rather continuous and diffuse, unruptured, giving a general 'color' to space. We may establish here a link with Schafer's 'keynote', designating, in a soundscape, those sounds heard without being listened to, giving the soundscape (or time-image) its implicit identity (1977: 9). Background wefts will be transcribed as wide diffuse halos.

2. Soundmarks, as defined by Schafer, are the sonic equivalent of landmarks, salient by some characteristics and recognized by a community as representative of their space (1977: 10). This may mean that a sound should be internally stable, consistent in its temporal unfolding, relatively clear and contrasted with the background, recurrent enough that it would give the time-image its explicit identity. Soundmarks will be transcribed as determinate forms occupying a consequent amount of space.

3. Acousmatic animals are the 'autonomous spectromorphological entities' described by Khosravi, whose clarity and behavior may facilitate their perception as living, self-conscious organisms. These entities are not sounds revealing the presence of animals, but become animals themselves (2012: 44-45). Animals could be solitary or swarming. According to their saliency and to their repetition, they may also play the role of soundmarks or background wefts in complex textures. Acousmatic swarms will be transcribed as groups of little forms occupying space; acousmatic solitary animals will be transcribed as determinate forms associated with dotted lines to indicate movement.

4. Lastly, signals are those salient entities with an articulatory role (Schafer 1977: 10). In the context of the time-image, signals will designate salient and clear montage points, articulating the sound flow by cutting from one sequence to the next. Signals will be transcribed as two vertical bars illustrating rupture, while continuous change will be transcribed as arrows.

The following is my interpretation of the first section of Chat Noir, inspired by the perspective developed thus far. Rather than inquiring with diverse listeners on their experience of the work when listening to it in this way, I preferred the realization of an analysis resulting from my own experience of it. This is because asking listeners would have implied a rather lengthy explanation about the framework, and it would have been extremely 
complicated, if not entirely impossible, to verify that they were, actually, listening to the work in the way described here.

Furthermore, as I said above, a listening behaviour does not impose any content on a piece, it defines the framework in which to listen to the piece. There could thus be other interpretations, maybe radically different ones, using the same framework, with different analysts. Therefore the fact that the analysis is presented the way it is here is not so much to describe an actual listening experience of the work, but rather to describe a potential listening experience, resting on the delineated perspective as a necessary condition.

\subsubsection{Chat Noir as a time-image}

In the first section, the high B is clearly the most salient sound, because of its characteristics as well as because of its repetition in the second subsection. I will consider it a soundmark, as it appears to me as the main marker of one identity of the work: a high-pitched harmonic sound, modulated and sustained. The articulation leading to it $\bigcirc$ could be described as a signal, because of its trigger-like nature. The harmonic weft $\xi^{3}$ delineating the whole-tone field will be described as a background weft, a keynote, because of its unchanging nature, its diffuseness and its low intensity. The articulation gone, the high B and the weft constitute the only two entities to be heard for the first 30 seconds of the piece, illustrated in the first picture of Figure 4 . The soundmark is generally centered, the weft is more diffuse.

While the weft's timbre darkens slowly $w^{3}$, a new background weft is revealed internally swarming (2) and occupying all the width of our acousmatic screen. At a certain point, we don't see the soundmark anymore, only the darker, closer to earth, sounds. An animated entity emerges, moving through space as if on its own - , which I'll describe as a solitary acousmatic animal, because of its saliency and its energetic movement. We have a new soundscape in front of us, illustrated in the second picture of Figure 4. Between the first two pictures, the arrow represents a gradual transition along 20 seconds, which we can see as a camera travelling, from looking up at the soundmark to looking down at the shadowy land which it dominates. No time has passed yet, no energy has been expended by any goal-oriented character.

We've been given this space to contemplate for some time, when the first montage cut happens. This is a signal, repeated three times, revealing at last the hand of the person who crafted this image. A new background weft appears 0 , represented as a halo in the third picture of Figure 4, and its internal life is given for us to see for some 15 seconds. Its harmonicity and its relatively high position in spectral space links it to the first weft and to the soundmark. Maybe they are close to it somewhere. Indeed, after having been announced by its attached signal, the soundmark appears again, and the camera moves away to be able to see the whole of it, englobing both the soundmark and the keynotes. While the first animal can be heard far away, another animal $D^{--}$, radically different, briefly appears on-screen. The internal life of the low weft, closer than it was the first time, may again be understood as a swarm of acousmatic rodents or insects, occupying space around the soundmark.

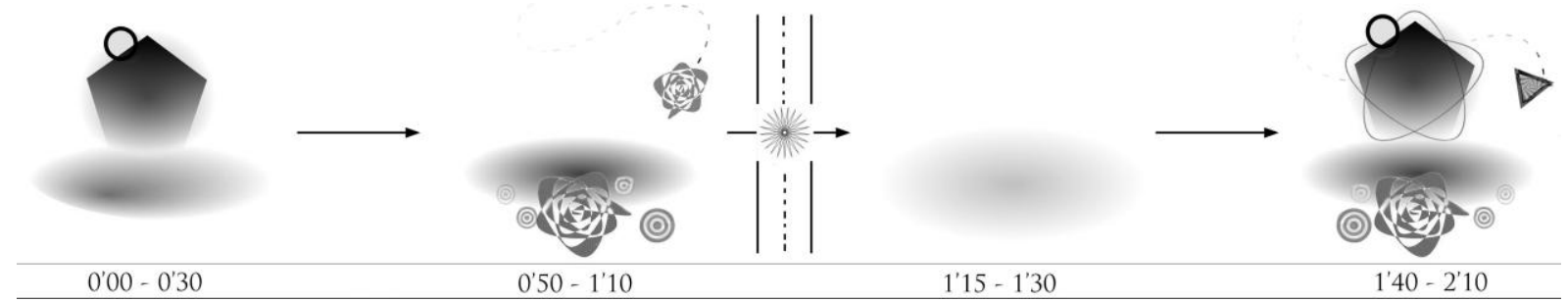

Figure 4. Chat Noir as a time-image - spatial score for the first two minutes of the work.

On the whole, we could understand this whole section as framing different aspects of a single space. Following this perspective, the soundmark is the pillar around which little and big animals live, run, play with each other in tall grass constituted by the background wefts. We could even look at the whole of Chat Noir, and obtain Figure 5 , which represents the unified space of the piece. Once represented and remembered in this way, the world of Chat Noir (and most certainly a lot of other pieces) can be explored mentally, establishing relations that weren't necessarily heard in the piece but that still exist as another way of framing this world. At this point, chronology, energy, flow, etc., might all be discarded as relevant elements to the formal experience of the piece. Music in the moment (Levinson 1997, 2013) is overcome, not to go towards an architectonic view of form, but rather towards a spatial and systemic one. 


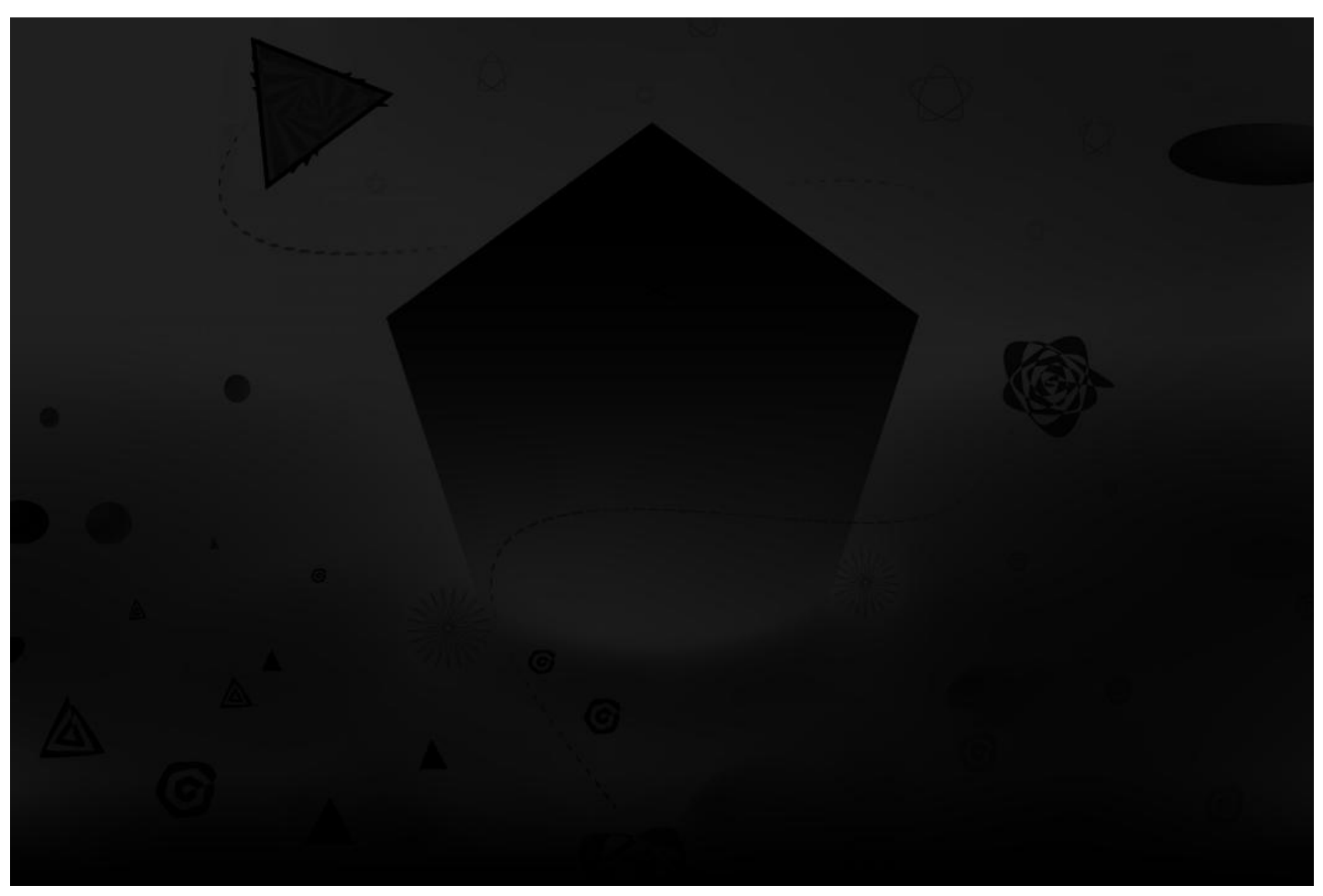

Figure 5. Chat Noir as a time-image - holistic spatial score for the whole work.

\section{Concluding remarks}

Whereas Deleuze talked about the time-image as a new aesthetics of cinema, emerging post-WW2, my perspective here has been slightly different: rather than an aesthetic concept, the time-image has been taken as an aesthesic concept, as a "model for listener-oriented analysis". Therefore, an analysis such as the one proposed here does not seek to represent the (communicative) will of the composer, it offers listener a specific perspective on the work.

As was the case with the notion of rhizome (as a counterpart to the genealogical tree), the idea of music as an art of space might actually need to be explained for listeners to be able to apprehend the work in that way: here space is not a new parameter of sound to be articulated through time, it is a new character of form, a new container for specific formal functions and listening behaviours.

\section{References}

AlCAZAR, Antonio (2015). 'La escucha atenta como base para el análisis de las músicas electroacusticas'. Musimédiane, 8. [http://musimediane.com/numero8/ALCAZAR/].

ANDERSON, Elizabeth (2011). Materials, Meaning and Metaphor: Unveiling Spatio-Temporal Pertinences in Acousmatic Music. Ph.D. thesis in composition, London City University.

BATTIER, Marc (2013). 'La composition concrète et acousmatique : Pierre Schaeffer, le Groupe de recherches musicales et leurs précurseurs'. In: N. Donin \& L. Feneyrou (eds.), Théories de la composition musicale au XXe siècle. Lyon : Symétrie. 689-709. 
BÉRIACHVILI, Georges (2010). L'espace musical : concept et phénomène - à travers l'avant-garde des années 1950-60 (Stockhausen, Xenakis, Ligeti...), Ph.D. thesis in musicology, Université de Rouen.

BRELET, Gisèle (1949). Le temps musical : essai d'une esthétique nouvelle de la musique. Paris: PUF.

BRUNSON, William (forthcoming). Narrativity and formal aspects of electroacoustic music. Ph.D. thesis, De Montfort University (Leicester).

CiPOllone, Elvio (2013). 'Le temps représenté'. In: J.M. Chouvel \& X. Hascher (eds.), Esthétique et cognition. Paris: Publications de la Sorbonne. 299-318.

COUPRIE, Pierre (2015). 'Le développement d'un outil d'aide à l'analyse musicale : bilan et perspectives musicologiques'. In: N. Marty (ed.), Musiques électroacoustiques / Analyses $\leftrightarrow$ Écoutes, Paris: Delatour, 157-170. [forthcoming]

Delalande, François (1989). 'La terrasse des audiences du clair de lune de Debussy : essai d'analyse esthésique'. Analyse Musicale, 1: 75-84.

(1998). 'Music analysis and reception behaviours: Sommeil by Pierre Henry'. Journal of New Music Research, 27 (1/2): 13-66.

(2010). 'Signification et émotion dans les conduites d'écoute musicale'. In: M. Ayari \& H. Makhlouf (eds.), Musique, Signification et Émotion. Paris: Delatour. 231-248.

(2013). Analyser la musique. Pourquoi, comment ?. Paris: Ina.

DeleuZE, Gilles et GUATTARI, Félix (1980). Milles plateaux (Capitalisme et schyzophrénie 2). Paris: Éditions de Minuit.

Deleuze, Gilles (1983). L'image-mouvement (Cinéma 1). Paris: Éditions de Minuit.

DeLEUZE, Gilles (1985). L’image-temps (Cinéma 2). Paris: Éditions de Minuit.

JoHnson, Robert (1991). Owning Your Own Shadow: Understanding the Dark Side of the Psyche. New-York: Harper-Collins.

KhOSRAVI, Peiman (2012). Spectral Spatiality and the Acousmatic Listening Experience: The Birth of Autonomous Spectromorphological Entities. Ph.D. thesis in composition, London City University.

Kramer, Jonathan D. (1988). The Time of Music: New Meanings, New Temporalities, New Listening Strategies. New-York: Schirmer Books.

LANDY, Leigh (2012). Making Music with Sounds. New-York \& London: Routledge.

LANGLOIS, Philippe (2012). Les cloches d'Atlantis. Musique électroacoustique et cinéma, archéologie d'un art sonore. Paris: MF.

LEVInSON, Jerrold (1997). Music in the Moment. New-York: Cornell University Press.

LEVINSON, Jerrold (2013). 'Concaténationisme, architectonisme et compréhension musicale'. In: J.M. Chouvel \& X. Hascher (eds.), Esthétique et cognition. Paris: Publications de la Sorbonne. 113-128.

MARTY, Nicolas (2012). 'Presque Rien, de l'anecdote au surréalisme'. Musurgia, 18 (4): 61-78. 
(2014). 'Journey into Space: an analysis'. eOrema, 2. [http://www.orema.dmu.ac.uk/ ?q=content/journey-space-\%E2\%80\%93-analysis]

(2015a). 'La narrativisation acousmatique - Compte-rendu d'expérience'. Musimédiane, 8. [http://musimediane.com/numero8/MARTY/].

(2015b). 'An interview with Elizabeth Anderson'. eContact!, 17 (2) [forthcoming]

MARTY, Nicolas \& TERRIEN, Pascal (2015). 'L'entretien d'explicitation pour analyser l'écoute des musiques acousmatiques'. In: N. Marty (ed.), Musiques électroacoustiques / Analyses $\leftrightarrow$ Écoutes, Paris: Delatour, 67-86. [forthcoming]

SCHAEFFER, Pierre (1966). Traité des objets musicaux. Paris: Seuil.

SCHAFER, R. Murray (1977). The Soundscape - The Tuning of the world. Rochester: Knopf.

SMALLEY, Denis (2007). 'Space-form and the Acoustic Image'. Organised Sound, 12 (1): 35-58.

STOCKHAUSEN, Karlheinz (1988). 'Momentform - Nouvelles corrélations entre durée d'exécution, durée de l'œuvre et moment'. Contrechamps, 9: 101-120.

Sutton, Damian \& MARTIN-JONeS, David (2008). Deleuze Reframed. London/ New-York: I.B. Tauris. 